\title{
THE RISE OF TRAIL RUNNING IN SOUTH AFRICA: POSSIBILITIES FOR SMALL-SCALE SPORTS TOURISM
}

\author{
Tracey McKAY* \\ Department of Environmental Science, University of South Africa, \\ Preller St, Muckleneuk, Pretoria, ooo2, Africa de Sud, e-mail: mckaytjm@unisa.ac.za \\ Lynsey McEWAN \\ Gordon Institute of Business Studies, University of Pretoria, \\ Lynnwood Rd, Hatfield, Pretoria, ooo2, Africa de Sud, e-mail: lynseymcewan@gmail.com \\ Melissa BAKER \\ Department of Environmental Science, University of South Africa, \\ Preller St, Muckleneuk, Pretoria, ooo2, Africa de Sud, e-mail: Bakermsp@unisa.ac.za
}

Citation: McKay T., McEwan L., \& Baker M. (2019). THE RISE OF TRAIL RUNNING IN SOUTH AFRICA: POSSIBILITIES FOR SMALL-SCALE SPORTS TOURISM. GeoJournal of Tourism and Geosites, 26(3), 930-942. https://doi.org/10.30892/gtg.26320-408

\begin{abstract}
Between 2011 and 2016, South Africa witnessed a threefold increase in the number of official trail running events. Given South Africa's historical love affair with ultra-long-distance road running, and with health and physical activity becoming increasingly important, such growth is not surprising. This growth reflects international sports trends, with trail running one of the fastest growing segments of this industry. It is argued here that trail running tourism has major growth potential in South Africa, as trail runners are prepared to travel to 'destination' race events. Such events can boost the local tourism economy, attracting domestic and international tourists. Locations in South Africa that have natural physical beauty, are scenic, remote or off the usual tourism track could leverage their physical assets to attract participants to 'destination trail running events'. To that end, this study explores the local trail running market by firstly investigating some of South Africa's iconic long-distance trail running events, and, secondly, profiling trail running tourists and investigating their spending behaviour. As research on the nature of active sports tourism and the characterisation of the South African market for iconic destination trail running events is limited, the study fills an important gap in the literature.
\end{abstract}

Keywords: trail running, South Africa, destination marketing, sport tourism, local economic development,

\section{INTRODUCTION}

It has been argued by Nyikana and Tichaawa $(2018,1)$ that sport tourism can make a significant contribution to local economic development in Africa. In particular, they

\footnotetext{
* Corresponding author
} 
maintain that "sport tourism events can be used to promote previously neglected and underdeveloped destinations". In particular Hemmonsbey and Tichaawa (2019, 254) feel that non-mega events, of which running events would be one, hold particular opportunities for "establishing tighter social networks and connections" to the local community. Thus, such events should be encouraged by local governments as a way of stimulating the local economy. With respect to running, South Africa is home to two globally famous long-distance road-running events, namely: The Comrades Marathon and Two Oceans Marathon. Both these events attract tens of thousands of running tourists, including many international competitors, with positive economic impacts on the provinces of Kwa-Zulu Natal and the Western Cape respectively (Saayman \& Saayman, 2012; Fairer-Wessels, 2013; Maharajh, 2015). However, the focus on these events has resulted in a neglect of other smaller, non-mega running events. Events that, we argue here, have the potential to grow local economies in precisely the way Nyikana and Tichaawa (2018) and Hemmonsbey and Tichaawa (2019) envisage. In particular, offroad or trail running has grown enormously in popularity with a proliferation of trail running events across South Africa in recent years (Christie, 2016). Despite this, the size of the South African domestic tourism market for destination trail running events has not been reported on. Thus, the purpose of this study is to explore the South African longdistance trail running community through the lens of sport tourism. In this regard, we deemed long distance running races as events which are $21 \mathrm{~km}$ or more in length.

The study establishes who the typical trail runner is, and argues that it contributes to local economies as a type of niche sporting tourism. The paper posits that hosting long distance trail running events can help boost both domestic and international tourism in South Africa, thus assisting this key economic sector to grow (Visser \& Rogerson, 2014; Alexandris, 2016). This is crucial as, currently, South Africa's tourism sector is struggling. For example, decline in both international arrivals and domestic travellers. As a result, the total number of day trips in South Africa have decreased from 48 million in 2014 to 47 million in 2017, and overnight trips from 47 million in 2014 to 44 million for the same period (StatsSA, 2017; 2018). Even worse is that StatsSA (2019) reports that foreign arrivals were lower for Quarter One 2019 than for the same quarter in 2017. Thus, being able to leverage the trail running market to generate local economic growth is a distinct possibility for South Africa, especially for small towns in remote areas.

\section{Sport Tourism}

Globally sport tourism is one of the fastest growing types of niche tourism; although the definition and scope of sport tourism is greatly debated (Deery et al., 2004; Gibson, 2004). A broad definition includes event tourism, along with competitive and recreational sporting activities. Gibson (2005, 134) defines sport tourism as "leisurebased travel that takes individuals temporarily outside of their home communities to participate in physical activities, to watch physical activities, or to venerate attractions associated with physical activities". This broad definition includes many different types of tourists, from those travelling to attend a Roland-Garros tennis match to those playing golf whilst on holiday. Thus, researchers have defined several subcategories of sport tourism. These include: (1) Event sport tourism, which is travel as a spectator to an organized sport event, such as include to attend a Soccer World Cup match; (2) Nostalgia sport tourism, which is travel for sport-related purposes such as to visit sports stadiums or museums; (3) Integral sport tourism, travel for activities where "sport and the tourism are part and parcel of the same experience" (Sugden, 2007, 236); and (4) Active sport tourism, travel to spectate or participate in leisure sporting activities; such as travel to undertake a mountain biking trail (Gibson, 2005). Many of these sub-categories do overlap, which makes the precise study of the phenomenon a challenging task (Jago et al., 2003). As 
this research focuses on travelling to participate in a trail running event, it falls into the active sport tourism category. It is, then, to trail running that this paper will now turn.

\section{The rise of trail running}

Globally, the popularity of trail running is rising. In an effort to understand this phenomenon, researchers across the Global North and South have begun to investigate it (Navalta et al., 2018). Despite this, scholarly research into trail running remains in its infancy (Havlick et al., 2016; Urbaneja \& Farias, 2018). One important theme that has emerged in the (sparse) literature are the environmental impacts of trail running. Havlick et al. (2016) argue that trail running (along with hiking and mountain biking) has a negative impact on the biophysical environment, despite the activity being promoted as 'sustainable'. As a result, $\mathrm{Ng}$ et al. (2017) argue that trail running in protected areas should be regulated. This includes limiting the number of events and participants. In addition, the growth in the sheer number of trails is such that they can become a threat to public recreational space (Newsome \& Davies, 2009; Ballantyne et al., 2014; Barros \& Pickering, 2015). Thus, there have been calls to conduct research on the ecological impacts of trail running, as well as into user conflicts between trail runners and those who use public recreational space for other activities such as walking, cycling, or dog walking (Moore, 2007; Newsome, 2014). Another research theme arising in relation to trail running is that of climate change. Importantly, some European skiing resorts are adopting trail running as a means to diversify their product offerings and pursue new markets as they can longer guarantee snowfall (Richard et al., 2010).

Other emerging areas of research include the local economic impacts of trail running events and the demographic characteristics of participants (Hoffman \& Wegelin, 2009; Wicker \& Hallman, 2013; Soler-Vayá \& González, 2017; Navalta et al., 2018; Urbaneja \& Farias, 2018). Some scholars focus on the intrinsic (push) and extrinsic (pull) factors to determine what drives participants to travel to participate in such running events (Lough et al., 2016; Aicher \& Newland, 2017). Tourism researchers have also looked at the potential of promoting trail running as a niche sport tourism market (Perrin-Malterre \& Chanteloup, 2018). In this regard Newland \& Aicher (2018) argue that host communities seeking to attract new tourists to their destination should focus on identifying moderate-distance running events, as these seem to attract the most runners.

Research has also been conducted on what factors are driving the growth of trail running, such as the adoption of a 'fitness culture' and the rise of social media - which together have created a reason and a means to promote trail running. A study by Boudreau \& Giorgi (2010) found that trail running helps to reduce job stress and improve work-productivity. The study recorded important psychological benefits associated with trail running such as increased self-efficacy, greater discipline, more mental focus on career goals, a more positive attitude to life, enhanced work performance, increased problem-solving, improved time management, and better organization skills.

A noticeable trend in trail running is an increasing rate of female participation (Hoffman \& Wegelin, 2009; Navalta et al., 2018). For example, female participation in the 100-mile North American Moab Trail race went from 12 percent of the field in 1986 to 22 percent in 2007. Between 2012 and 2015 on the $21 \mathrm{~km}$ route (of the same race) there was also an increase in the number of female participants. According to Running USA (2007), female runners increased from (on average) 11 percent of the field in 1980 to 40 percent in 2007. The increase is such, that a renowned roadrunner Grete Waitz, attributed the growing popularity of marathons as a whole to this increase in the number of female participants (Kislevitz, 1999). Navalta et al. (2018) suggest social changes, such as women gaining equal rights and a drive for female empowerment, may be encouraging woman to enter such events, as well as to make use of public spaces for recreational purposes 
(Wesely \& Gaarder, 2004). The social nature of participating in a trail race and increasing levels of personal safety may also be creating the conditions that, then, enable women to undertake such events in ever greater numbers. Choate (2008) asserts that female runners benefit from participation in terms of feeling increased self-confidence, being more outgoing (overcoming shyness), and gaining relief from depression. Despite such research, the profile of the South African trail running participant remains unknown.

\section{Sports Tourism Research in South Africa}

Given South Africa's natural beauty and the generally hospitable climate, outdoor sport is a popular pastime. But as a field of academic inquiry, sports tourism is still in its infancy in South Africa (Tassiopoulos \& Haydam, 2008). Part of this is due to the role sport played in both fostering, and fighting, the apartheid regime. For example, on the one hand, the apartheid government segregated sport along racial lines; while on the other hand, the anti-apartheid movement harnessed sport as a platform for resistance against apartheid. This included imposing sporting sanctions on South Africa (Keech \& Houlihan, 1999). Thus, for a long time sport was highly politicized in South Africa.

Consequently, sport and sport tourism in South Africa has a unique narrative in comparison to the experiences of the Global North. In particular, a lack of critical research within the niche market of sport tourism was evident during the apartheid years. In line with changes in the political environment of South Africa post 1990, research on sport tourism strengthened once the sport boycott ended (Visser \& Hoorgendoorn, 2011). Thus, sport tourism "has emerged as one of the fastest-growing spheres of the leisure travel market and has become a subject of interest at academic and governmental levels alike" (Kotze \& Visser, 2008, 61). Crucially, the pace and trajectory of sport tourism research has been strongly influenced by post-apartheid policies. In 1995, the State identified sport tourism as a strategic tool to stimulate economic development and social regeneration (Swart \& Bob, 2007). Subsequently, the 1996 Tourism White Paper highlighted sports tourism as a vehicle for development. In addition, a State initiated sport tourism campaign, known as 'South African Sports Tourism' (SAST), was launched in 1997 with the aim of developing the potential of this niche tourism sector (Ritchie \& Adair, 2002). Thus, along with many other countries, South Africa highlighted sport tourism as a means to attract international tourists (Gibson, 2005). Unfortunately, research suggests a mismatch between policy and implementation. Swart (2005) asserts that since SAST's launch, no tangible progress has been made, and to date, the initiative remains inactive. Worse is that the Tourism Growth Strategy (released in 2002) seems to have dropped sport tourism as a primary driver for development. This trend of neglect continued with the 2004-2007 Domestic Tourism Growth Strategy (DEAT, 2004). This decline in government support is reflected in the findings of the Global Competitiveness Project (Department of Environmental Affairs and Tourism, 2004). Results of this Global Competitiveness Project reveal that demand for sports tourism, amongst both international and domestic tourists, is weak. Thus, this niche market needs much attention in terms of marketing (Tassiopoulos \& Haydam, 2008).

From a South African research perspective, prior to 2008, sport tourism studies focused on supply-side issues such as improvement of sport performance and the marketing of sports offerings (Tassiopoulos \& Haydam, 2008). Another major focus of research was South Africa's involvement in Sport-Mega Events (SME) (Cornelissen, 2005; 2011). Thus, research into SMEs, such as the FIFA Soccer World Cup, Rugby and Cricket World Cups, has been extensive (Giampiccoli et al., 2015). Much attention has been paid to the economic and social impacts on host communities of SMEs, especially pertaining to employment creation, poverty reduction, local economic development, small enterprise creation, and post-event impacts (Swart et al., 2008; Rogerson, 2009; 
Hemmonsbey and Tichaawa, 2018). In that regard, Bama and Tichaawa (2012) have taken this further by analysing the environmental citizenship and sustainability of major sporting events. Other studies in sports tourism in South Africa include mountain biking, road running, golf tourism, and cycling (Kotze, 2006; Kotze \& Visser, 2008; Du Preez \& Lee, 2015). Assessing the viability of recurring sporting events of a local nature has also become popular, with studies by Turco et al (2003) which focused on the socio-economic impact of sport tourism events such as the Comrades Marathon, the Investec Cycling Tour, and the Vodacom Beach Africa festival on the City of Durban. Others have followed suit, with Kotze (2006) assessing the economic impact of the Two Oceans Marathon; Saayman et al. (2008) investigating the economic impact of visitor spending during the Cape Argus Cycle Tour; and Saayman and Saayman (2012) examining determinates for visitor spending at three major sport events in South Africa.

A call to investigate the sustainability and socio-economic impacts of hosting a recurring local sport event was answered by Giampiccoli et al. (2015), who found that over a five-year period, hosting the Comrades Marathon, the Dusi Canoe Marathon and the Midmar Mile generated approximately the same economic impact for Kwa-Zulu Natal as the once off 2010 FIFA World Cup. Their study has been supported by the work of Saayman and Saayman (2012) who estimated that the 2011 Comrades Marathon generated a total direct spending of approximately R76 million for KwaZulu-Natal. While Maharajh (2015) similarly estimated that the 2010 Comrades Marathon race generated in excess of R130 million for the cities of Durban and Pietermaritzburg. This suggests that recurring local or regional events are more sustainable, less expensive, and have a significantly greater, positive, long-term local economic impact than SMEs (Daniels and Norman, 2003; Gibson et al., 2003, Gibson et al., 2012; Giampiccoli et al., 2015). In this regard, Kotze and Visser (2008) concluded that South Africa should work to promote one-day local sporting events. In line with Kotze and Visser (2008), Daniels and Norman (2003) suggest smaller-scale events generate revenue for the local economy, create a sense of comradery and pride amongst locals, as well as increasing awareness of the host as a tourist destination. Green and Chalip (1998) found that sport tourists use events as opportunities to socialise and celebrate the particular sporting subculture.

In this way, travel associated with sport has become a way to create personal identity and participate in authentic experiences (Moularde \& Weaver, 2016). The greater the attachment to a particular sporting personal identity, the more likely the individual is to undertake sports related travel, creating a virtuous economic and social circle. This is especially true for long-distance runners, for example. McGehee et al. (2003) found that highly involved roadrunners made many overnight trips with the purpose of participating in running events. Accordingly, Ogles and Masters (2003) suggest that long-distance running tourism has particularly high tourism potential (due to the high levels of personal commitment required). From a social perspective, a number of studies have shown that long-distance runners find that the activity promotes a sense of personal achievement and heightens self-esteem (Bond \& Batey, 2005). In terms of the Comrades Marathon, it was found that achievement, commitment, and socialisation were the key motives for participation (Kruger \& Saayman, 2013). If this is the case, then it is highly likely that long-distance trail running events may also have the same potential as a source of both ardent domestic and international tourists. However, Kruger and Saayman (2013) concluded that the motives for participation differ per sporting event. Therefore, participants should not be treated as a homogenous group for the purposes of event design and marketing. Thus, if local trail running destination events are to be promoted, a detailed knowledge of who the trail running tourist is, and what the potential economic size of the demand market is, is necessary. 


\section{MATERIALS AND METHODS}

An exploratory design, case study approach, and quantitative survey methodology was adopted for this study (Saunders \& Lewis, 2012). The study focusses on six one day long-distance trail running events in South Africa that were designated as iconic events due to their long history or status within the trail running community. The six events were: (a) The SkyRun; (b) The Ultra Trail Cape Town; (c) The Rhodes Run; (d) The Otter African Trail Run; (e) The Peninsula Ultra fun run (PUFfer), and (f) The Hobbit trail run. The survey sought to profile the trail runners who had participated in these events, or wanted to, as well as determine their spending behaviour with respect to long-distance trail running destination events (and the sport in general). An online Facebook survey amongst trail runners was undertaken. In particular, two Facebook community groups dedicated to long-distance trail running in South Africa were targeted, namely: "\#TeamTrail \#LoveTrail" and "South Africa Trail Running"1. Permission from the relevant Facebook group admins was granted. The Facebook survey was piloted with eight self-identified long-distance trail runners. The results were analysed using SPSS. In order to mitigate the risk of a homogenous sample of only active Facebook users, respondents were asked to share the online survey amongst their other long-distance trail running friends and networks. Thus, snowball sampling was used to increase the sample size.

The total number of respondents to the survey was 118. Due to the purposive convenience sampling method and the online nature of the surveys used, the findings may not be statistically representative of the population. In order to strengthen the validity of the data, the online survey data was compared to that of runners who participated in the 2017 Ultra Trail Cape Town event, using data provided by the event organisers ${ }^{2}$. It was found that much of the demographic findings between the online Facebook survey and the data provided by Ultra Trail Cape Town are in alignment. It should also be noted that the study did not include multi-day stage trail running events in order to limit the scope.

\section{RESULTS}

South Africa is home several iconic long-distance trail runs, namely: (a) The $52 \mathrm{~km}$ Rhodes Run (established 1989); (b) The SkyRun (established 1991/2); (c) The 8okm Peninsula Ultra fun run (PUFfer) (established 1995) (d) The Hobbit trail run (established 2006) and (e) The 44km Otter African Trail Run (established 2008). Most, however, have a small field. For example, in 2017, the SkyRun had only 339 participants across all three events $(100 \mathrm{~km}, 65 \mathrm{~km}$ and $42 \mathrm{~km})$, the Rhodes Run had only 228 participants, while the Otter African Trail Run is always capped at 250 entrants per year. Similarly small is the Hobbit trail run with two categories, a $90 \mathrm{~km}$ and a $38 \mathrm{~km}$, with an approximate total field of 200. New long-distance trail running destination events are also small, such as the Karkloof10o and the $53 \mathrm{~km}$ Whale of Trail in the Western Cape. The Karkloof1oo has two categories: a $100-$ mile $(160 \mathrm{~km})$ and a 50 mile $(80 \mathrm{~km})$ category. It is a very small event with less than 100 people. Similarly, the Whale of Trail event comprises under 120 participants. This makes the new Ultra Trail Cape Town (established 2013) very different as it attracted over 1000 participants in 2017. Figure 1 presents the geographical distribution of these iconic events, with all of them hosted in just three provinces, namely the Western Cape, The Eastern Cape and KwaZulu-Natal. Notable is the dominance of coastal provinces in the provision of these races, as well as their geographical relationship with significant transport routes. Thus, access to locations is an important consideration that race event organisers have to take into account when considering hosting such an event.

1 \#TeamTrail \#LoveTrail with 918 members as of 12 July 2017, found at https://www.facebook.com/groups/ teamtrail.lovetrail/ and South Africa Trail Running with 1720 members as of 12 July 2017, found at https:// www.facebook.com/groups/SATrailRunning /

2 See https://www.ultratrailcapetown.com/ [Accessed 3 May 2018]. 


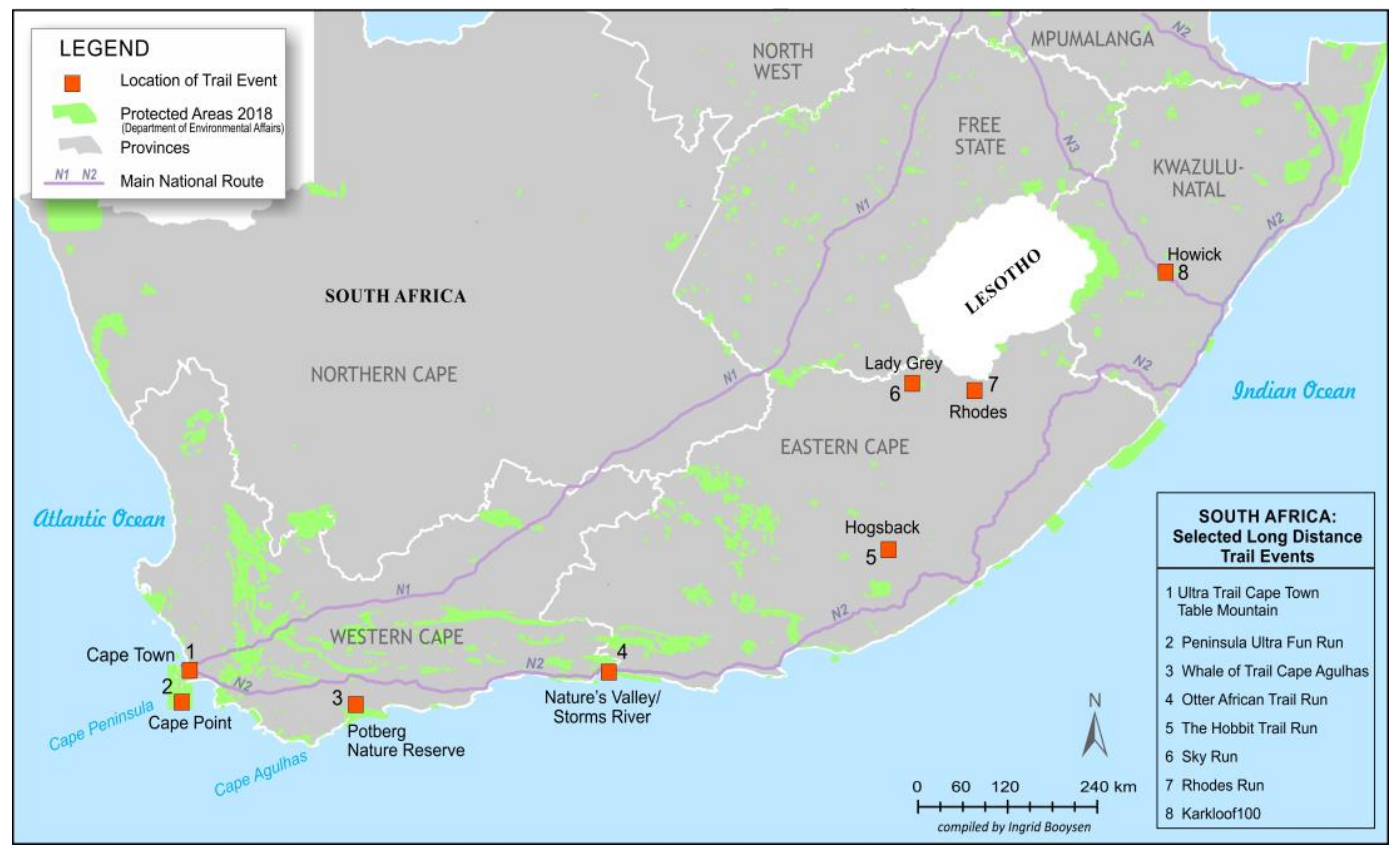

Figure 1. Distribution of iconic long-distance trail races across South Africa

Compared to most iconic long-distance trail running events, the Ultra Trail Cape Town, which takes place over and near Table Mountain, is a 'mega' event in trail running terms, attracting 1019 runners in 2017 from over 40 countries. There were 176 participants on the $100 \mathrm{~km}$ route, 324 on the $65 \mathrm{~km}$ route and 519 participating in the $35 \mathrm{~km}$ event. The event formed part of the Ultra Trail World Tour. Of the participants in the $100 \mathrm{~km}$ event, only $2 \%$ were Black African , $15 \%$ were female. The bulk $(60 \%)$ were aged between 30 and 39 (average age 37 years). Thus, the vast majority of participants were young white men. Half (50\%) were South African. Half (50\%) were international tourists and 30\% were domestic tourists. The remaining 20\% were from Cape Town itself.

Only 70 percent of starters completed the $100 \mathrm{~km}$ event. Of the participants in the $65 \mathrm{~km}$ event, only $2 \%$ were Black African, $21 \%$ were female and the bulk (40\%) were aged between 30 and 39 (average age 38 years). Thus, although white men still dominated, this distance category attracted more females. Most participants (62\%) were South African, with $38 \%$ international tourists. Of the South African's 22\% had travelled to Cape Town for the event. Almost all (91\%) starters completed the event. Of the participants in the 35km event, only 3\% were Black African, 39\% were female and $42 \%$ were aged between 30 and 39 (average age 37 years). Most participants (82\%) were South African, 18\% were international tourists. As for the $65 \mathrm{~km}$ event, some $22 \%$ of the South Africans had travelled to Cape Town to participate in the event. Completion rates for the $35 \mathrm{~km}$ event were high, with 94 percent of starters finishing the event. Thus, a typical participant was white, male, a domestic tourist and 37 years of age. Race completion and female participation rates increase as distance decreases. However, participation by groups other than white men was extremely low. In terms of the online Facebook survey of trail runners, the largest proportion (42\%) of the respondents were between 30 and 39 years of age. In terms of race, the overwhelming majority (95\%) were white. In terms of highest level of education, 54\% of respondents held a postgraduate degree. These high education levels were consistent with the high-income profile in which: $26 \%$ fell in the highest income bracket, with a household income of over R1 
ooo ooo per annum3; however, the largest portion of respondents (28\%) had a pre-tax annual household income of R201 000 - R400 000. Regarding job description, 54\% of the respondents worked as professionals, and $32 \%$ worked in managerial or technical roles. The findings indicate that the activity is a typically high-income domain.

Table 1. Long-distance trail running profile of respondents (Data source: Facebook survey, 2017)

\begin{tabular}{|c|c|}
\hline \multicolumn{2}{|c|}{ Level of experience as a trail runner? } \\
\hline Beginner 14 (12\%) & Intermediate $55(47 \%)$ \\
\hline Experienced 39 (33\%) & Advanced $10(8 \%)$ \\
\hline \multicolumn{2}{|c|}{ Years of involvement in trail running? } \\
\hline Less than one year $10(9 \%)$ & One to two years $26(22 \%)$ \\
\hline Three to four years $36(31 \%)$ & Five to six years $24(20 \%)$ \\
\hline Seven to eight years $10(9 \%)$ & More than nine years $12(10 \%)$ \\
\hline \multicolumn{2}{|c|}{ How many trail running events do you take part in (average per year)? } \\
\hline None $1(1 \%)$ & One or two $12(10 \%)$ \\
\hline Three or four $30(25 \%)$ & Five or six $29(25 \%)$ \\
\hline Seven or eight $14(12 \%)$ & Nine or more $32(27 \%)$ \\
\hline \multicolumn{2}{|c|}{ Number of times you travel more than $100 \mathrm{~km}$ to a trail running event per year } \\
\hline Zero $11(9 \%)$ & Once or twice $54(46 \%)$ \\
\hline Three or four times $32(27 \%)$ & Five or six times $13(11 \%)$ \\
\hline \multicolumn{2}{|c|}{ More than seven $8(7 \%)$} \\
\hline \multicolumn{2}{|c|}{ Estimated trail running mileage in the last 12 months? } \\
\hline Under $100 \mathrm{~km} 16(14 \%)$ & $100-299 \mathrm{~km} 28(24 \%)$ \\
\hline $300-499 \mathrm{~km} 27(23 \%)$ & $500-699 \mathrm{~km} 14(12 \%)$ \\
\hline \multicolumn{2}{|c|}{ More than $700 \mathrm{~km} 33(28 \%)$} \\
\hline
\end{tabular}

Table 1 details the long-distance trail running behaviour of the respondents. Most respondents rated their level of trail running experience as intermediate (47\%) or experienced (33\%); while many have been involved in the sport for three to four years (31\%). Respondents spend a large amount of time engaging in the activity, with some $28 \%$ estimating their trail running mileage for the last year to be greater than $700 \mathrm{~km}$. In terms of event behaviour, the respondents are active in events: $27 \%$ took part in more than nine race events per year. Additionally, a large majority (73\%) have taken part in an event longer than $21 \mathrm{~km}$ in the past year. Regarding travel to destination events, $46 \%$ have travelled further than $100 \mathrm{~km}$ on one or two occasions to take part in an event in the last year, while only $9 \%$ of respondents have not travelled to do so. When it came to iconic events, most respondents had taken part in at least one of the six designated iconic events, while $15 \%$ had taken part in two or more of the different events. As illustrated in Figure 2, the most popular event for the respondents was the Otter African Trail Run, followed by the SkyRun and then the new Ultra Trail Cape Town. Spending patterns of respondents on their long-distance trail running activities are given in Table 2. The largest contributors to the total spend were shoes (average of R2 513) and event entries (average of R2 424) (Table 2). Followed by transport to events (average of R2 322) and accommodation (R2 165). That said, the bulk of respondents spent less than R2 999 per annum on event entries and less than R1999 on shoes (38\%). Such a low average spend on shoes means that most are likely only buying one pair a year, as they are costly specialist items. Respondents typically spent less on apparel, with the majority of 37\% spending between R1 ooo and R1 999 annually. In terms of total spend; the average was R11 373 per person per year. The study did not ask participants to quantify what they spend on food and race related items, however, as depicted in Figure 3, race related items such as drinks and snacks are costly.

3 In November 2017 the ZAR to USD exchange rate was R13 to one USD. 


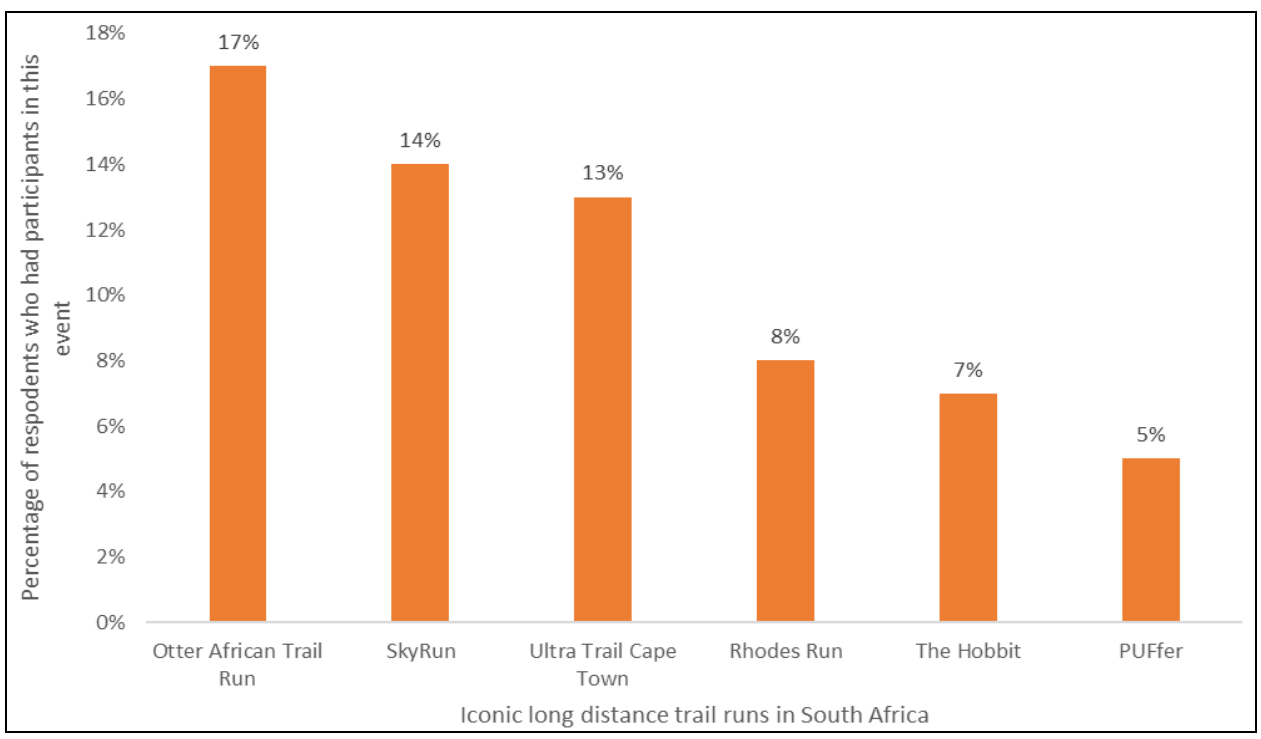

Figure 2. Respondent participation in iconic events

Table 2. Spending patterns of respondents on their long-distance trail running activities (Data source: Facebook survey, 2017)

\begin{tabular}{|l|c|c|c|c|c|c|c|}
\hline $\begin{array}{c}\text { Spend } \\
\text { Category }\end{array}$ & $\begin{array}{c}\text { Less than } \\
\text { R1000 }\end{array}$ & $\begin{array}{c}\text { R10oo - } \\
\text { R1999 }\end{array}$ & $\begin{array}{c}\text { R200o - } \\
\text { R2999 }\end{array}$ & $\begin{array}{c}\text { R3000 - } \\
\text { R3999 }\end{array}$ & $\begin{array}{c}\text { R400o- } \\
\text { R4999 }\end{array}$ & $\begin{array}{c}\text { More than } \\
\text { R5000 }\end{array}$ & Avg \\
\hline Event Entries & $22 \%$ & $19 \%$ & $32 \%$ & $9 \%$ & $8 \%$ & $12 \%$ & R2 424(21\%) \\
\hline Shoes & $3 \%$ & $38 \%$ & $32 \%$ & $10 \%$ & $9 \%$ & $8 \%$ & R2 513(22\%) \\
\hline Apparel & $25 \%$ & $37 \%$ & $18 \%$ & $9 \%$ & $3 \%$ & $7 \%$ & R1 949(17\%) \\
\hline Transport & $14 \%$ & $34 \%$ & $30 \%$ & $7 \%$ & $8 \%$ & $9 \%$ & R2 322 20\%) \\
\hline Accommodation & $26 \%$ & $19 \%$ & $31 \%$ & $13 \%$ & $5 \%$ & $6 \%$ & R2 165(19\%) \\
\hline
\end{tabular}

Events, and accommodation at events, tended to be, on average, the costliest for many respondents. Figure 4 indicates what respondents said would be the maximum amount of money they are willing to spend on an event (if it included tented accommodation). The largest portion of respondents (36\%) were willing to spend a maximum of $\mathrm{R}_{3}$ 000, while $23 \%$ would spend $\mathrm{R}_{5} 000$ and $10 \%$ indicated they would spend R10 ooo or more. This is a substantial amount of money. Thus, their engagement with sport tourism made up a substantial portion of the total annual average spend.

\section{DISCUSSION}

The study has demonstrated that there has been a rise in the number of high profile long-distance trail running destination events in South Africa in recent years. What is also clear is that there is demand for such events, with many 'repeat clients' (the same runners entering the same race every year) as some $27 \%$ of online respondents said they take part in more than nine events in any single calendar year. As the iconic trail events are both small in number and (most) have a small field, it is likely that demand for this kind of sports tourism remains unmet. The popularity of the new Ultra Trail Cape Town is also an indication thereof. In addition, while participation levels for black people and women are currently low, it is also highly likely that this will change over time, such that eventually 
the demographics of trail running will come to resemble that of long-distance road running in South Africa. Thus, demand for these kind of events is likely to grow, in line with the general growth trajectory seen in road running in South Africa (Mandla Radebe, pers comm, 2018). Furthermore, the study has shown that trail runners have high levels of disposable income, which enables them to spend money on their sport.

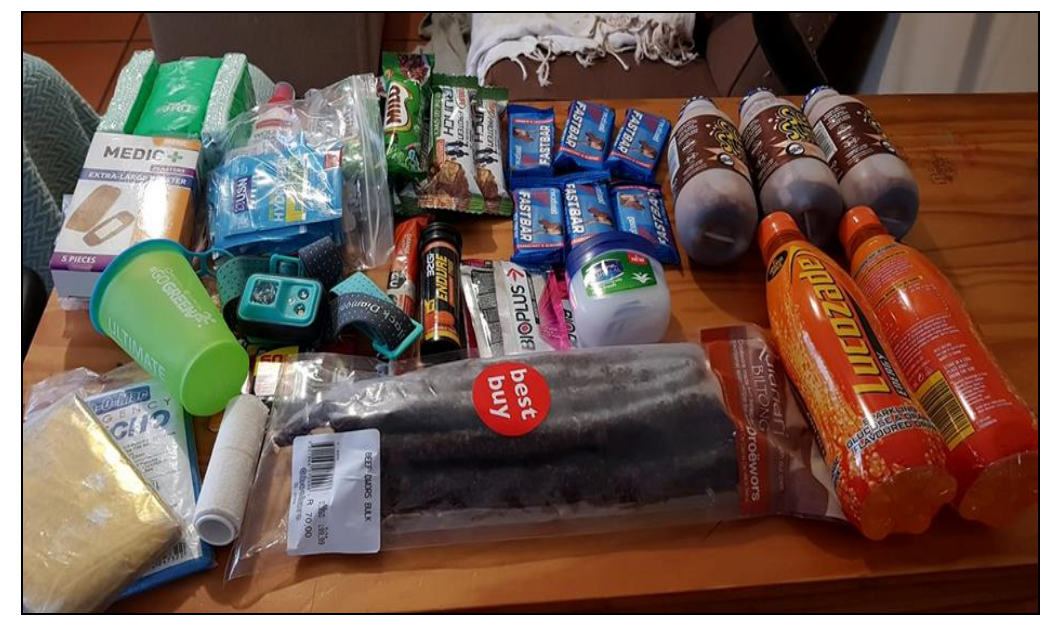

Figure 3. Race day supplies, photograph taken a few days ahead of the 2018 Karkloof 100 event. Estimated cost R500 (Source: Hanno Langenhoven, 2018)

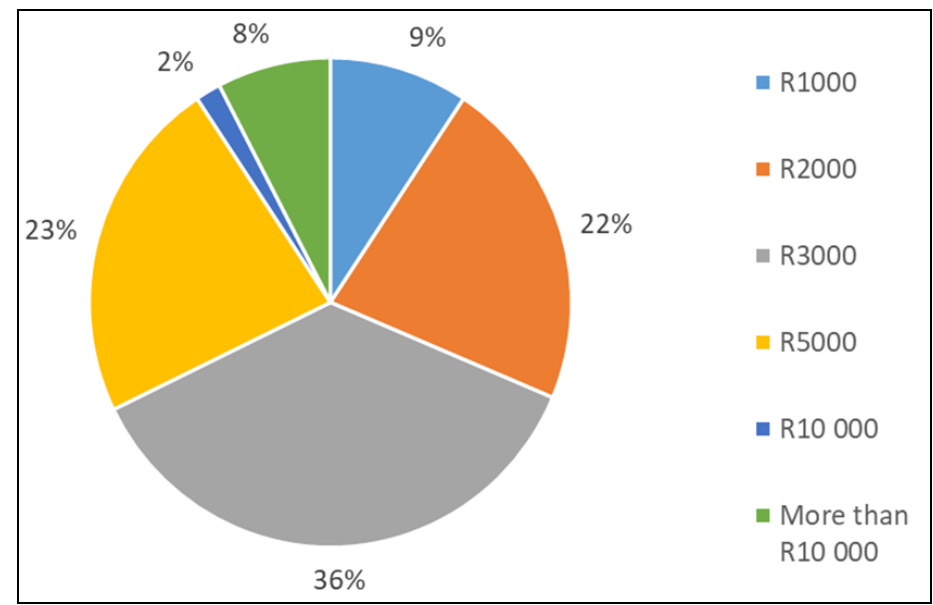

Figure 4. Maximum willing to spend on an event including tented accommodation

For example, respondents to the online survey reported spending substantial sums of money on trail running related equipment and events. While trail running events and equipment are costly, which may explain the high spend, it is also highly likely that people are willing to make sacrifices in other areas of their life to re-direct funds to this particular sports activity. For example, many are willing to travel to participate in such events and are not shy to purchase shoes, apparel and race-related foodstuffs. It is also highly possible that their actual spend was underreported (such as for shoes and race related foodstuffs) and so these spending estimates are conservative. Taking event entries, travel and accommodation purchases as an indication, it is highly likely that hosting such events 
can boost local economies, in the same way other recurring sports events have, and South African tourism in general. Taking into account international trends and findings with respect to trail running, it is argued here that the rural, 'rugged' nature of the Eastern Cape Province, for example, is an ideal location to grow such tourism in South Africa. Thus, small Eastern Cape towns that have the necessary physical resources such as mountains, rivers, a coastline or open veld could, in conjunction with the trail running community (and event organisers), opt to host such an event (McKay, 2017).

However, as there are concerns about the possible negative impacts of trail running on the biophysical environment, it is recommended that the number of events should be increased, rather than increasing the number of participants per event. Trail events also need to have a range of distances to attract the best overall mix of participants in terms of domestic and international tourists and in terms of male and female runners. In particular, international tourists will only travel for seriously long distances (over $65 \mathrm{~km}$ ) but having exclusively long distances (more than 21kms) will preclude female runners. Thus, a combination of longer and shorter distances within one event is recommended. In this way, this form of sport tourism may be able to grow in a sustainable manner.

\section{CONCLUSION}

The recent increase in the number of long-distance trail running events and participants is an indication that trail running has major growth potential in South Africa. Importantly, the willingness of trail runners to spend money on event entries, transport and accommodation is an indication that if South Africa were to leverage its physical potential to host such events, the tourist economy as a whole may benefit. As the trail running community is attracted to destination events, both domestic and international tourists can be attracted to localities, especially the neglected or 'off the beaten track' ones, such as the Eastern Cape province of South Africa. Crucially, small towns located in areas with natural physical beauty should consider developing, marketing, and hosting such events as hosting such a recurring local sport event could have significant long-term benefits for local communities.

\section{Acknowledgements}

The authors would like to thank the participants in the online survey, as well as the organisers of the Ultra Trail Cape Town event for access to their data. A special thanks to Milton Milaras for language editing and critical review, and to Ingrid Booysen for the cartographic material. We are also most grateful to the critical reviewers for their insightful comments. Errors and omissions are our own.

\section{REFERENCES}

Aicher, T. J., \& Newland, B. L. (2017). To explore or race? Examining endurance athletes' destination event choices. Journal of Vacation Marketing, 29(3) https://doi.org/10.1177/1356766717736364.

Alexandris, K. (2016). Testing the role of sport event personality on the development of event involvement and loyalty. International Journal of Event and Festival Management, 7(1), 2-20. https://doi.org/10.1108/ IJEFM-10-2015-0041.

Ballantyne, M., Gudes, O., \& Pickering C.M. (2014). Recreational trails are an important cause of fragmentation in endangered urban forests: A case-study from Australia. Landscape and Urban Planning, 130, 112-124.

Bama, H.K.N., \& Tichaawa, T.M. (2015). Major sporting events and responsible tourism: Analysis of the 2013 Africa Cup of Nations (AFCON) tournament in Port Elizabeth, South Africa. African Journal for Physical, Health Education, Recreation and Dance, Supplement 1 (December), 205-219.

Barros, A., \& Pickering, C.M. (2015). Impacts of experimental trampling by hikers and pack animals on a highaltitude alpine sedge meadow in the Andes. Plant Ecology \& Diversity, 8, 265-276.

Bond, K. A., \& Batey, J. (2005). Running for their lives: A qualitative analysis of the exercise experience of female recreational runners. Women in Sport and Physical Activity Journal, 14(2), 69-82.

Boudreau, A. L., \& Giorgi, B. (2010). The experience of self-discovery and mental change in female novice athletes in connection to marathon running. Journal of Phenomenological Psychology, 41(2), 234-267. 
Choate, M. (2008). Marathon participation: A study of motivation and training habits or running affiliated with a charitable cause. (Doctoral dissertation in Sports Management). United States Sports Academy, Retrieved from ProQuest Dissertations and Theses database. (ATT 3329383).

Christie, S. (2016, July). The business of trail running. Finweek, 34-36. https://www.fin24.com/Finweek /Featured/the-business-of-trail-running-20160718 [Accessed 13 Sept 2018].

Daniels, M. J., \& Norman, W. C. (2003). Estimating the economic impacts of seven regular sport tourism events. Journal of Sport Tourism, 8(4), 214-222.

Deery, M., Jago, L., \& Fredline, L. (2004). Sport tourism or event tourism: Are they one and the same? Journal of Sport and Tourism, 9(3), 235-245.

Du Preez, M., \& Lee, D. E. (2015). The economic value of mountain biking in the Baviaanskloof Mega Reserve, Eastern Cape, South Africa: A travel cost analysis using count data models. Economic Research Southern Africa (ERSA). ERSA working paper $546 \mathrm{https} / /$ econrsa.org/system/files/publications/ working_papers/working_paper_546.pdf [Accessed 16 Sept 2018].

Fairer-Wessels, F. A. (2013). Motivation and behaviour of serious leisure participants: the case of the Comrades Marathon. South African Journal for Research in Sport, Physical Education and Recreation, 35(2), 83-103.

Giampiccoli, A., Lee, S. S., \& Nauright, J. (2015). Destination South Africa: Comparing global sports megaevents and recurring localised sports events in South Africa for tourism and economic development. Current Issues in Tourism, 18(3), 229-248.

Gibson, H. (2004). Moving beyond the "what is and who" of sport tourism to understanding "why" of sport tourism to understanding "why", Journal of Sport Tourism, 9(3) https://doi.org/10.1080/1477508042000320232.

Gibson, H. (2005). Sport Tourism: Concepts and Theories. An Introduction. Sport in Society, 8(2). https://doi.org/10.1080/17430430500101996.

Gibson, H. J., Kaplanidou, K., \& Kang, S. J. (2012). Small-scale event sport tourism: A case study in sustainable tourism. Sport Management Review, 15(2), 160-170.

Gibson, H. J., Willming, C., \& Holdnak, A. (2003). Small-scale event sport tourism: Fans as tourists. Tourism Management, 24, 181-190.

Green, C., \& Chalip, L. (1998). Sport tourism as the celebration of subculture. Annals of Tourism Research, 25(2), 275-291.

Havlick, D.G., Billmeyer, E., Huber, T., Vogt, B. \& K. Rodman (2016). Informal trail creation: hiking, trail running, and mountain bicycling in shortgrass prairie. Journal of Sustainable Tourism, 24:7, 1041-1058 https://doi.org/10.1080/09669582.2015.1101127.

Hemmonsbey, J., \& Tichaawa, T. (2018). The effects of major sport event leveraging for tourism and destination branding: The case of South Africa as an emerging destination. GeoJournal of Tourism and Geosites, 21(1), 213-282.

Hemmonsbey, H. \& Tichaawa, T.M. (2019). Using non-mega events for destination branding: A stakeholder perspective. GeoJournal of Tourism and Geosites, 24 (1), 252-266.

Hoffman M.D., \& Wegelin JA. (2009). The Western States 100-Mile Endurance Run: participation and performance trends. Medicine and science in sports and Exercise, 41(12), 2191-2198.

Jago, L., Chalip, L., Brown, G., Mules, T., \& Ali, S. (2003). Building Events into Destination Branding: Insights from Experts. Event Management, 8(1), 3-14.

Keech, M., \& Houlihan, B. (1999). Sport and the end of apartheid. The round table, 88(349), 109-121.

Kislevitz, G. (1999). First marathons: Personal encounters with the 26.2-mile monster. Halcottsville, New York: Breakaway Books.

Kotze, N. (2006). Cape Town and the two oceans marathon: The impact of sport tourism. Urban Forum, 17(3), 282-293.

Kotze, N., \& Visser, G. (2008). Sport Tourism: Comparing Participant Profiles and Impact of Three One-Day Events in South Africa, Africa Insight 38(3), 61-72.

Kruger, M., \& Saayman, M. (2013). Who are the comrades of the Comrades Marathon? South African Journal for Research in Sport, Physical Education and Recreation, 35(1), 71-92.

Lough, N. L., Pharr, J. R., \& Geurin, A. (2016). I am bolder: A social cognitive examination of road race participant behavior. Sport Marketing Quarterly, 25(2), 90-102.

Maharajh, A. (2015). A comparative socio-economic impact analysis of the 2010 Comrades Marathon on the cities of Durban and Pietermaritzburg. PhD in the Faculty of Health Sciences, University of KwaZuluNatal. Retrieved from https://researchspace.ukzn.ac.za/xmlui/bitstream/handle/10413/13743/ Maharajh_Ashok_2015.pdf?sequence=1\&isAllowed=y [Accessed 18 Sept 2018].

Mandla Radebe. (2018). Managing Director, Central Gauteng Athletics, Gauteng, South Africa, personal communication.

McGehee, N. G., Yoon, Y., \& Cardenas, D. (2003). Involvement and travel for recreational runners in North Carolina. Journal of Sport Management, 17 (3), 305-324.

McKay, T., 2017. The adventure tourism industry of South Africa: organisation, space and structure, unpublished $\mathrm{PhD}$ thesis, University of Johannesburg. Retrieved from https://ujcontent.uj.ac.za/vital/access/manager /Repository/uj:23896?site_name=GlobalView [Accessed 1 Sept 2019].

Moore, B. (2007). The environmental impact of running. Retrieved from http://news.runtowin.com/ 2007/10/15/the-environmental-impact-of-running.html [Accessed 12 Oct 2018].

Moularde, J., \& Weaver, A. 2016: Serious about leisure, serious about destinations: mountain bikers and destination attractiveness. Journal of Sport and Tourism, 20, 285-303.

Navalta, J. W., Montes, J., Tanner, E. A., Bodell, N. G., \& Young, J. C. (2018). Sex and Age Differences in Trail Half Marathon Running. International Journal of Exercise Science, 11(6), 281. 
Newland, B.L., \& T. J. Aicher (2018) Exploring sport participants' event and destination choices, Journal of Sport \& Tourism, 22:2, 131-149 https://doi.org/10.1080/14775085.2018.1436464.

Newsome, D. (2014). Appropriate policy development and research needs in response to adventure racing in protected areas. Biological Conservation, 171, 259-269.

Newsome, D., \& Davies, C. (2009). A case study in estimating the area of informal trail development and associated impacts caused by mountain bike activity in John Forrest National Park, Western Australia. Journal of Ecotourism, 8, 237-253.

Ng, S. L., Leung, Y. F., Cheung, S. Y., \& Fang, W. (2018). Land degradation effects initiated by trail running events in an urban protected area of Hong Kong. Land Degradation \& Development, 29(3), $422-432$.

Nyikana, S. \& Tichaawa, T. (2018). Sport Tourism as a Local Economic Development Enhancer for Emerging Destinations, EuroEconomica, 37( 2), 1-11.

Ogles, B. M., \& Masters, K. S. (2003). A typology of marathon runners based on cluster analysis of motivations. Journal of Sport Behavior, 26(1), 69.

Perrin-Malterre, C., \& Chanteloup, L. (2018). Hiking and snowshoeing in the Hautes-Bauges (Savoie-France): study of sports practices and forms of experience of nature. Journal of Alpine Research | Alpine Geography Review, (106-4). DOI: 10.4000/rga.3924.

Richard, D., George-Marcelpoil, E., \& Boudieres, V. (2010). Climate change and the development of mountain areas: what do we need to know and for what types of action? Journal of Alpine Research, (98-4), DOI: 10.4000/rga.1334.

Ritchie, B., \& Adair, D. (2002). The growing recognition of sport tourism. Current Issues in Tourism, 5(1) https://www.tandfonline.com/doi/abs/10.1080/13683500208667903.

Rogerson, C.M. (2009). Mega-events and small enterprise development: The 2010 FIFA World Cup opportunities and challenges. Development Southern Africa, 26(3), 337-352.

Saayman, M., \& Saayman, A. (2012). The economic impact of the Comrades Marathon. International Journal of Event and Festival Management, 3(3), 220-235. https://doi.org/10.1108/17582951211262675.

Saayman, M., Rossouw, R., \& Saayman, A. (2008). Economic impact of visitor spending at the Cape Argus Pick 'n Pay Cycle Tour. Africa Insight, 38(3), 100-122.

Saunders, M., \& Lewis, P. (2012). Doing research in business and management: An essential guide to planning you project. London: Pearson Education.

Sugden, J. (2007). Running Havana: Observations on the Political Economy of Sport Tourism in Cuba. Leisure Studies, 26(2), 235-251. https://doi.org/10.1080/02614360600896734

Swart, K. (2005). Strategic planning-implications for the bidding of sport events in South Africa. Journal of Sport Tourism, 10(1), 37-46.

Swart, K., \& Bob, U. (2007). The eluding link: Toward developing a national sport tourism strategy in South Africa beyond 2010. Politikon, 34(3), 373-391.

Swart, K., Bob, U., \& Mbaze-Ebock Arrey, V. (2008). Sport events and their socio-economic impact: Residents' perceptions of the Isuzu Berg River Canoe Marathon, Africa Insight, 38 (3), 123-134.

Tassiopoulos, D., \& Haydam, N. (2008). Golf tourists in South Africa: A demand-side study of a niche market in sports tourism. Tourism Management, 29(5), 870-882. https://doi.org/10.1016/j.tourman.2007.10.005

Turco, D. M., Swart, K., Bob, U., \& Moodley, V. (2003). Socio-economic impacts of sport tourism in the Durban Unicity, South Africa. Journal of Sport Tourism, 8(4), 223-239.

Urbaneja, J.S., \& Farias, E. I. (2018). Trail running in Spain. Origin, evolution and current situation; natural areas. Federación Española de Asociaciones de Docentes de Educación Física (FEADEF) ISSN: Edición impresa: 15791726. Edición Web: 1988-2041 (www.retos.org). https://dialnet.unirioja.es/servlet/articulo?codigo=6367738.

Soler-Vayá, F., \& San Martín González, E. (2017). The promotion of rural tourism through trail running: the case of Carrícola in the La Vall d'Albaida region (Spain). STEPS. Magazine of Tourism and Cultural Heritage, 15 (1), 49-69.

Visser, G., \& Hoogendoorn, G. (2011). Current paths in South African tourism research. Tourism Review International, 15(1-2), 5-20.

Visser, G., \& Rogerson, C. M. (2014). Researching the South African tourism and development nexus, GeoJournal 6o(3), 201-215.

Wesely J.K., \& Gaarder E. (2004). The gendered "nature" of the urban outdoors - Women negotiating fear of violence. Gender and Society 18(5):645-663.

Wicker, P., \& Hallmann, K. (2013). Estimating consumer's willingness-to-pay for participation in and traveling to marathon events. Event Management, 17(3), 271-282.

*** DEAT (Department of Environmental Affairs and Tourism). (2004). Domestic tourism growth strategy: 2004-2007. Pretoria: DEAT \& SA Tourism. https://www.gov.za/sites/default/files/growthstra_o.pdf, [Accessed 18 Sept 2018].

*** Running USA. (2007). RRIC Annual Marathon Report 2007. Retrieved June 22, 2009, from http://www.runningusa.org/media/wire2008/Wire2008-31.html.

*** StatsSA (2017a). Domestic Tourism Survey 2014 http://www.statssa.gov.za/?p=5431 [Accessed 13 Sept 2018].

*** StatsSA (2018). Domestic Tourism Survey 2018 http://www.statssa.gov.za/publications/Po3521/P0352120 17. pdf [Accessed 17 July 2019].

*** StatsSA (2019) Tourism and migration, March 2019, Statistical Release Po351 http://www.statssa. gov.za/publications/Po351/Po351March2019.pdf [Accessed 2 Sept 2019].

Submitted:

10.07.2019
Revised:

11.10.2019
Accepted and published online 15.10 .2019 